Article

\title{
The Effect of the Hydraulic Retention Time on the Performance of an Ecological Wastewater Treatment System: An Anaerobic Filter with a Constructed Wetland
}

\author{
María L. Merino-Solís ${ }^{\dagger}$, Edgardo Villegas ${ }^{\dagger}$, José de Anda ${ }^{\dagger}$ and Alberto López-López * \\ Environmental Technology, Research Center and Assistance in Technology and Design of Jalisco, \\ N.P.O., Normalistas 800, Guadalajara 44270, Jalisco, Mexico; \\ E-Mails: lucyms5@gmail.com (M.L.M.-S.); evillegas@ciatej.mx (E.V.); janda@ciatej.mx (J.A.) \\ $\dagger$ These authors contributed equally to this work. \\ * Author to whom correspondence should be addressed; E-Mail: allopez@ciatej.mx; \\ Tel.: +52-333-345-5200 (ext. 1600); Fax: +52-333-345-5200 (ext. 1001).
}

Academic Editor: Say-Leong Ong

Received: 18 December 2014 / Accepted: 19 February 2015 / Published: 17 March 2015

\begin{abstract}
This work assesses the performance of a municipal pilot wastewater treatment system employing an up-flow anaerobic filter (UAF) followed by a horizontal subsurface constructed wetland (HSSCW). This pilot scale demonstration project was implemented in a zone with subtropical climate in order to protect Lake Chapala from wastewater loads that are discharged by small communities in the Lake's vicinity. The filters were filled with tezontle as the media for biofilm support and the HSSCW was planted with two ornamental plants species, Canna hybrids and Strelitzia reginae. The experiment evaluated three hydraulic retention times (HRT) of 18, 28 and $38 \mathrm{~h}$ in the UAF, which corresponds to two, three and four days in HSSCW over 66 weeks. The mean efficiencies found for the complete system were $80 \%$ and $90 \%$ of BOD, $80 \%$ and $86 \%$ of COD, $30 \%$ and $33 \%$ of $\mathrm{N}_{\text {tot }}$ and between $24 \%$ and $44 \%$ of $\mathrm{P}_{\text {tot. }}$. It was possible to remove almost $80 \%$ of organic matter in $18 \mathrm{~h}$ in the UAF while the HSSCW reached $30 \%$ of removal for $\mathrm{N}_{\text {tot }}$ in a HRT of three days. As expected, the UAF was responsible for removing most of the organic matter and the HSSCW removed most of the nitrogen.
\end{abstract}


Keywords: constructed wetland; up-flow anaerobic filter; organic matter removal; nutrient removal; hydraulic retention time (HRT)

\section{Introduction}

Untreated wastewater discharged by cities and small rural communities contains nutrients that alter lakes and streams by accelerating the eutrophication process and thus change the quality of freshwater bodies [1-3]. A convenient ecological alternative that works well for small rural communities is to treat the municipal wastewater through constructed wetlands $[4,5]$.

An artificial or constructed wetland is a natural treatment system designed and constructed to imitate hydrodynamic mechanisms as well as biogeochemical pollutant degradation processes that occur in natural wetlands, but with a greater degree of control over the hydraulic regime of the system [6]. The goal is to improve the quality of an effluent by optimizing the treatment systems [7]. A horizontal subsurface flow constructed wetland (HSSCW) includes low depth excavations or channels, emergent vegetation planted on a layer of soil of a porous or granular media that allows for the horizontal subsurface flow of the effluent. The permeable bed (formed by the granular media, the rhizomes and plant roots) is elevated and the water level is below the surface of the bed. Construction includes the placement of a plastic membrane for groundwater and soil protection and adequate inlet and outlet hydraulic structures to control water level [8-12]. Low energy requirements, easy operation and maintenance, modest installation and maintenance costs, minor sludge production, and the creation of a visually pleasing landscape are some advantages of this technology $[5,13,14]$. The clogging of granular media is one of the main operation problems in subsurface flow constructed wetlands [15]. It is linked to media type and it, in turn, is linked to hydraulic retention time since the hydraulic conductivity of porous media is very sensitive to media size and is influenced by particle size distribution and particle shape [16]. An adequate selection of granular media could decrease the estimated wetland area and improve the removal efficiencies $[4,17]$.

Constructed wetlands are commonly used for secondary treatment in small communities [8]. However, they need a large land area [18] and therefore, it is sometimes necessary to add a previous treatment stage to the natural treatment system $[18,19]$. Anaerobic processes are a treatment technology that can be effectively integrated with constructed wetlands because they require a very small input of energy, minimum investment and operational costs, generate less biosolids when compared to conventional aerobic systems, and they can prevent clogging [15,18,20,21]. The up-flow anaerobic filter (UAF), as part of this technology, is able to treat wastewater with different pollutant loadings and it is successfully used, specifically for small communities in warm climates, to achieve the desired water quality. In general, the UAF removes dissolved and suspended solids through close contact with anaerobic bacteria attached to the filter media $[22,23]$.

Both the wetlands and UAF wastewater treatment processes have been individually studied with good results. The UAF removes mainly organic matter in wastewater with low and high organic loads, while the HSSCW is capable of removing organic matter and nutrients and is commonly used to obtain secondary or tertiary effluent concentration levels [8,23-25]. In other words, combining an anaerobic 
reactor with a constructed wetland brings important benefits to the constructed wetlands system, such as the reducing of the required planted area, reducing of the retention time, and increasing of their life cycle $[18,20]$. Few studies have been conducted on this coupled treatment process.

The aim of this study was to determine the effect of the hydraulic retention time on the performance of the coupled treatment system, integrated with an up-flow anaerobic filter and a horizontal subsurface constructed wetland, operated under subtropical climate conditions. Moreover, it was to evaluate the constructed wetland efficiency considering its area reduction. Provisions were included that allowed the control of the hydraulic retention time (HRT) to assess the impact on the reduction of organic matter and nutrients.

\section{Materials and Methods}

\subsection{Treatment System Description}

The pilot-scale constructed wetland was built on the site of the municipal wastewater treatment plant for Chapala, Jalisco, Mexico. This town is located on Lake Chapala $\left(20^{\circ} 07^{\prime}-20^{\circ} 21^{\prime} \mathrm{N}\right.$ and $102^{\circ} 40^{\prime} 45^{\prime \prime}-103^{\circ} 25^{\prime} 30^{\prime \prime} \mathrm{W}$ ) at an altitude of $1524.6 \mathrm{~m}$ above sea level. This area has a semi-warm sub-humid climate with summer rain, dry and semi-warm winters and springs. According to Köppen-Geiger climate classification, it is defined as a subtropical humid climate (Cwa) making this proposal possible in this type of climate around the world [26,27].

Wastewater was diverted from the grit removal chamber at the wastewater treatment plant. Raw wastewater was pretreated with a UAF with a filling height of $90 \%$ and with the dimensions of $1.75 \mathrm{~m}$ deep, $4 \mathrm{~m}$ long and $2.3 \mathrm{~m}$ wide. UAF effluent flowed to the HSSCW with the dimensions of $0.6 \mathrm{~m}$ deep, $9.2 \mathrm{~m}$ long and $7.6 \mathrm{~m}$ wide. The system was designed to operate with a water flow rate of $11 \mathrm{~m}^{3} \cdot \mathrm{day}^{-1}$, in order to provide for 110 person equivalents (PE). Both, the UAF and the HSSCW use tezontle as biofilm support. Tezontle is the Indian name of a volcanic red-orange extrusive rock classified as part of the feldspar family. This material has a high porosity (up to $65 \%$ pore volume for grain size of 20-25 mm), and this characteristic gives it a high surface area to volume ratio $\left(390 \mathrm{~m}^{2} \cdot \mathrm{m}^{-3}\right)$ compared to synthetic media $\left(164 \mathrm{~m}^{2} \cdot \mathrm{m}^{-3}\right)$. It has been tested and used in a number of environmental applications [28], and it is inexpensive, since it is abundant in Mexico [29]. Furthermore, the material is considered inert, with $\mathrm{pH}$ values close to neutral, low cation exchange capacity, good ventilation and capacity in humidity retention depending on particle diameter [30]. While the UAF contains tezontle of 1 inch diameter, the HSSCW was backfilled with two layers: The first with $50 \mathrm{~cm}$ of tezontle of 1 inch diameter and the second with $10 \mathrm{~cm}$ of tezontle of 0.25 inch diameter. The porosity of clean tezontle, tested prior to the experiments was determined to be $58 \%$ (1 inch) and 60\% (0.25 inch), respectively. As part of the construction, an impermeable plastic liner of $1 \mathrm{~mm}$ thick HDPP (High Density Polypropylene) was installed at the bottom of the treatment unit to prevent groundwater contamination. In addition, an adjustable outlet was installed at the end of the bed, which permitted better water level control. The HSSCW was planted with two plant species, the first half with Canna hybrids and the second half with Strelitzia reginae. Around one hundred plants from each species were planted in a geometric pattern of quincunx with a distance of $0.5 \mathrm{~m}$ between each plant of Canna hybrids and $0.55 \mathrm{~m}$ between each Strelitzia reginae, which provided an initial plant density of three plants per $\mathrm{m}^{2}$. The warm climate enables 
the use of non-conventional species; Zurita et al., (2009) suggest that it is possible to produce commercial flowers in constructed wetlands without reducing the efficiency of the treatment system. Therefore, these plants can acclimate well and grow, and also give a pleasing appearance [29,31].

\subsection{Treatment System Monitoring}

Once construction was completed, a start-up period of six months was used before beginning the monitoring stage in order to ensure greater plant coverage, which suggests a stable performance for pollutant removal [32], since it provides microorganisms the opportunity to grow and to adhere to the surface roots of the planted species and to the solid-porous substrate. Figure 1 shows the cover plant in the constructed wetland.

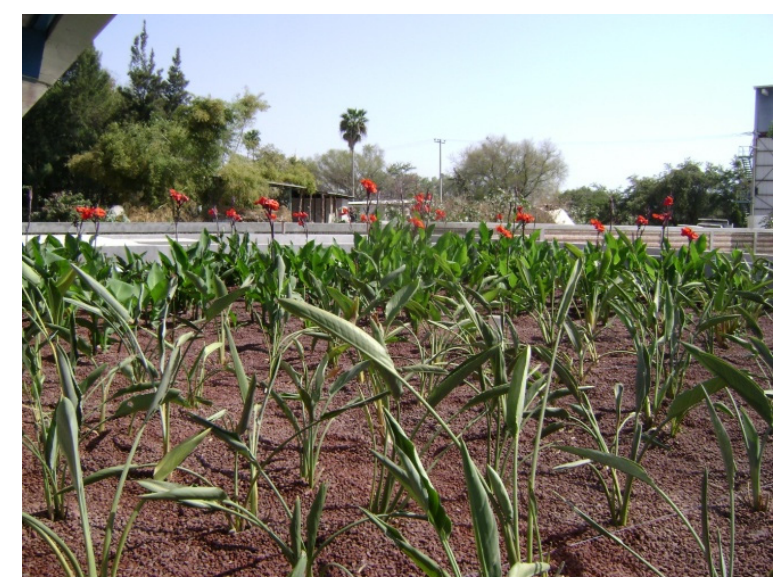

Figure 1. Wastewater Treatment System (field view).

Monitoring was conducted for 66 weeks, divided into three periods, to test the following hydraulic retention times: HRT1 corresponds to $18 \mathrm{~h}$ in the UAF and two days in the HSSCW, HRT2 was for $28 \mathrm{~h}$ in the UAF and three days in the HSSCW, and HRT3 was for $48 \mathrm{~h}$ in the UAF and four days in the HSSCW. In HSSFCW, the hydraulic retention time can vary between three and fifteen days to achieve an adequate treatment depending on pollutants to be removed [33]. Shorter retention times were chosen in order to test the response of the constructed wetland performance considering the previous addition of an anaerobic filter. The samples were collected weekly at four monitoring points along the treatment system (Figure 1): Influent (M1), outlet UAF/inlet HSSCW (M2), middle part of HSSCW (M3) and effluent (M4). For sampling points M2 and M4 (constructed wetland stage) it is important to point out that the first part of HSSCW was planted with different ornamental plants than the second stage. The sampling point M3 marked the separation between the two ornamental plants used. Strelitzia reginae was placed in the second part of the HSSCW because it has been proven that Canna hybrids adapt better to these conditions, showing high growth rates $[31,34]$.

\subsubsection{Water Quality Analysis}

Water samples were taken to measure five-day biochemical oxygen demand (BOD), chemical oxygen demand (COD), total nitrogen $\left(\mathrm{N}_{\text {tot }}\right)$, ammonia nitrogen $\left(\mathrm{NH}_{4}-\mathrm{N}\right)$, nitrite $\left(\mathrm{NO}_{2}\right)$, nitrate $\left(\mathrm{NO}_{3}\right)$ and total phosphorous $\left(\mathrm{P}_{\text {tot }}\right)$. The analytical methods used for the water quality analyses were in accordance with 
"Standard Methods for the Examination of Water and Wastewater" [35]. Total inorganic nitrogen was estimated as the sum of $\mathrm{NH}_{4}-\mathrm{N}, \mathrm{NO}_{2}$ and $\mathrm{NO}_{3}$. Some parameters were measured in the field, including Electrical conductivity (EC), $\mathrm{pH}$ (waterproof PC 300 hand-held pH/conductivity/TDS/Temperature meter OAKTON ${ }^{\circledR}$,Vernon Hills, IL, USA), temperature (Temp.), relative humidity (RH) (4184 Traceable ${ }^{\circledR}$, Jumbo Humidity/Temperature meter Friendswood, TX, USA) and dissolved oxygen (DO) (YSI 58 DO meter, Yellow Springs, OH, USA) in the constructed wetland with at a depth of $20 \mathrm{~cm}$ below the water table.

\subsubsection{Statistical Analyses}

A statistical model was utilized to determinate how pollutant concentration varied between sampling points and for different HRT. Data was assessed with a Nested Design with a crossover factor using Statgraphics Centurion $\mathrm{XVI}^{\circledR}$ (Warrenton, VA, USA) with a confidence level of 95\% [36]. The experiment was designed to compare the response (pollutant concentration) relative to categorical factors, including sampling points, HRT and time.

\section{Results and Discussion}

\subsection{In-Situ Field Conditions}

The major parameters that influence the removal mechanisms for nitrogen and organic matter in constructed wetlands are $\mathrm{pH}$, dissolved oxygen (DO) and temperature [17]. This is because organisms present in biological wastewater treatments are sensitive to these parameters. Table 1 shows the mean values and standard deviations for temperature, $\mathrm{RH}$ and $\mathrm{pH}$. The UAF stage of the process is represented by sampling points M1 (influent) to M2 (effluent), while the HSSCW stage is between sampling points M2 (influent) and M4 (effluent). A significant difference $(p \leq 0.05)$ between treatment stages was observed for $\mathrm{pH}$, but the $\mathrm{DO}$ did not show a significant difference between the sampling points M3 with a mean value of $0.71 \mathrm{mg} \cdot \mathrm{L}^{-1}( \pm 0.2)$ and M4 with a mean value of $0.8 \mathrm{mg} \cdot \mathrm{L}^{-1}( \pm 0.2)$ in the three tested HRTs.

Table 1. Mean values ( $\pm \mathrm{SD}^{\mathrm{a}} n=40$ ) of temperature (Temp.) and relative humidity $(\mathrm{RH})$ for environmental conditions and $\mathrm{pH}$ in every sampling point.

\begin{tabular}{|c|c|c|c|c|}
\hline & arameter & HRT1 & HRT2 & HRT3 \\
\hline & emp. $\left({ }^{\circ} \mathrm{C}\right)$ & $23.2 \pm 1.9$ & $21.7 \pm 1.8$ & $24.6 \pm 1.4$ \\
\hline & RH (\%) & $49.8 \pm 10.5$ & $50.3 \pm 9.8$ & $42.9 \pm 9.4$ \\
\hline \multirow{4}{*}{$\mathrm{pH}$} & M1 & $7.4 \pm 0.2$ & $7.1 \pm 0.3$ & $7.2 \pm 0.2$ \\
\hline & M2 & $6.9 \pm 0.2$ & $7.1 \pm 0.3$ & $6.9 \pm 0.2$ \\
\hline & M3 & $7.2 \pm 0.2$ & $7.4 \pm 0.2$ & $7.2 \pm 0.1$ \\
\hline & M4 & $7.2 \pm 0.3$ & $7.4 \pm 0.3$ & $7.1 \pm 0.1$ \\
\hline
\end{tabular}

Note: ${ }^{\text {a }} \mathrm{SD}$ : Standard deviation.

The $\mathrm{pH}$ reduction at sampling point $\mathrm{M} 2$ is due to anaerobic conditions that are predominate in the UAF ( $p \leq 0.05$ ). After M2, in almost all cases, a slight increase in $\mathrm{pH}$ was observed at the next sampling points (M3 and M4) because conditions in HSSCW are generally considered facultative. A straight-line correlation $(p \leq 0.05)$ was established between inlet and outlet $\mathrm{pH}$, for every stage that indicates a dependence on this parameter in the influent. In addition, the BOD removal efficiency and $\mathrm{N}_{\text {tot }}$ removal 
efficiency of UAF showed dependence on the inlet $\mathrm{pH}(p \leq 0.05)$ with $40 \%$ and $35 \%$, respectively, demonstrating that the efficiency of an anaerobic process depends mainly on $\mathrm{pH}$ [24].

The microorganisms responsible for nitrogen removal depend on temperature. The range of temperature favorable for nitrification is between 16.5 and $32{ }^{\circ} \mathrm{C}$ and for denitrification, the favorable temperature range is between 20 and $25{ }^{\circ} \mathrm{C}$ [17]. During the experiment, the recorded average temperature was $23{ }^{\circ} \mathrm{C}$ $( \pm 2.1)$ and the relative humidity was $48 \%( \pm 10 \%)$. The warm environmental conditions and the wastewater characteristics boosted the degradation of organic matter and nutrient removal.

\subsection{Performance and Removal Efficiencies}

Initially, organic matter decomposition is determined by the balance between organic matter load and oxygen transfer rate, which defines the predominant conditions of anaerobic and aerobic systems [9]. The organic matter, expressed as BOD and COD, is decomposed by aerobic and anaerobic microbial processes and also by physical processes, such as sedimentation and filtration. The Figure 2 shows the mean values for COD and BOD while the Figure 3a,b show all the COD and BOD data during the monitoring period. At each sampling point, the results showed a reduction across the treatment system, the $\mathrm{BOD} / \mathrm{COD}$ global ratio registered was 0.52 . It is possible that the UAF is responsible for the removal of most part of the organic matter (from $50 \%$ to $80 \%$ ). At sampling point M2, the lowest BOD/COD ratio (0.498) was found, indicating the presence of more oxidizable species that are biodegradables. In the beginning, the monitoring plan was scheduled to assess from three to five days, but once the treatment system behavior was observed and evaluated, the retention time of five days was changed to two days as it is shown in the Figure 3.

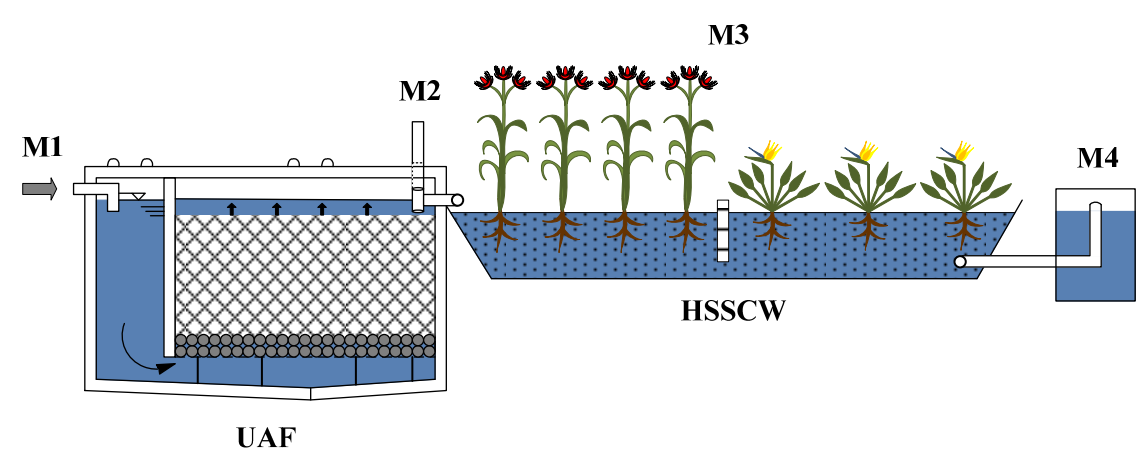

Figure 2. Sampling points in the wastewater treatment system. M1-influent; M2-outlet UAF/inlet HSSCW; M3-middle part of HSSCW; and M4-effluent.

It was observed that the greatest portion of the BOD was removed in the first half, from $42 \%$ to $53 \%$, while the second half of the HSSCW was between $8 \%$ and $19 \%$. This could be because the majority of the easily biodegradable BOD is removed in the first stage. The complete treatment system reached a BOD removal of $89.5 \%, 79.3 \%$ and $86.1 \%$ for the HRT1, HRT2 and HRT3, respectively. The COD removal values obtained were $84.2 \%$ for HRT1, $85.6 \%$ for HRT2 and $81.7 \%$ for HRT3. In the Table 2 is possible to observe the mean values for COD and BOD obtained in every sampling point and HRT. Significant differences $(p \leq 0.05)$ were found between the treatment stages (evaluated in the sampling points M1, M2 and M4), and between the HRTs as followed: HRT1 and HRT2, and HRT1 and HRT3. 

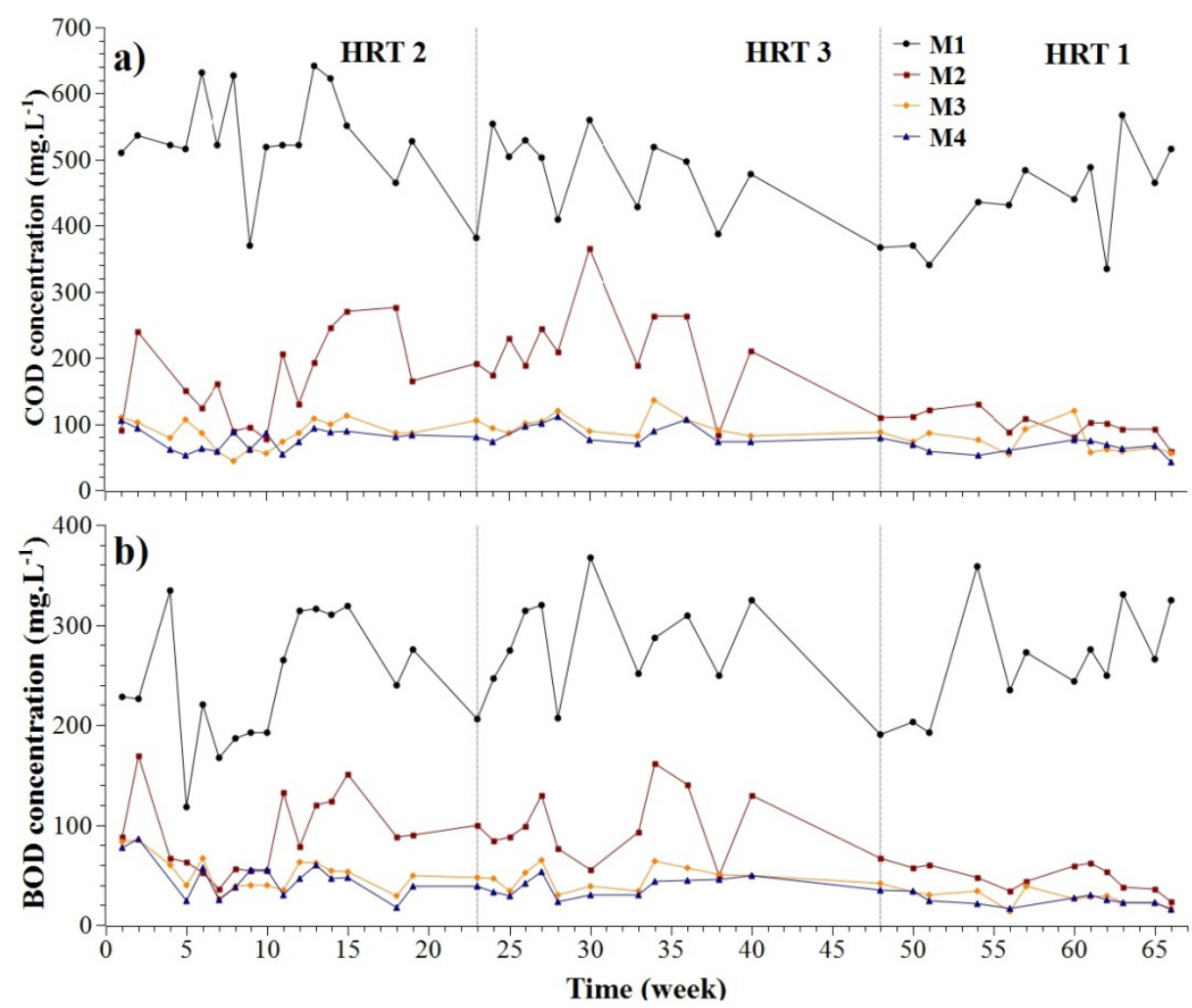

Figure 3. COD (a) and BOD (b) concentration for every sampling.

Table 2. Mean values $( \pm \mathrm{SD}, n=40)$ of $\mathrm{COD}$ and $\mathrm{BOD}\left(\mathrm{mg} \cdot \mathrm{L}^{-1}\right)$ in every sampling point and HRT tested.

\begin{tabular}{|c|c|c|c|c|c|c|}
\hline \multirow{2}{*}{$\begin{array}{c}\text { Sampling } \\
\text { Point } \\
\end{array}$} & \multicolumn{2}{|c|}{ HRT1 } & \multicolumn{2}{|c|}{ HRT2 } & \multicolumn{2}{|c|}{ HRT3 } \\
\hline & COD & BOD & COD & BOD & COD & BOD \\
\hline M1 & $\begin{array}{l}436.54 \\
(72.42)\end{array}$ & $\begin{array}{l}261.50 \\
(54.70)\end{array}$ & $\begin{array}{l}537.77 \\
(68.81)\end{array}$ & $\begin{array}{l}243.84 \\
(63.90)\end{array}$ & $\begin{array}{l}478.90 \\
(62.68)\end{array}$ & $\begin{array}{l}279.58 \\
(49.58)\end{array}$ \\
\hline M2 & $\begin{array}{c}98.76 \\
(19.88)\end{array}$ & $\begin{array}{c}48.73 \\
(14.10)\end{array}$ & $\begin{array}{l}167.80 \\
(68.16)\end{array}$ & $\begin{array}{c}90.35 \\
(40.31)\end{array}$ & $\begin{array}{l}217.58 \\
(66.97)\end{array}$ & $\begin{array}{c}100.25 \\
(33.92)\end{array}$ \\
\hline M3 & $\begin{array}{c}75.04 \\
(21.65)\end{array}$ & $\begin{array}{l}28.25 \\
(9.06)\end{array}$ & $\begin{array}{c}84.82 \\
(21.21)\end{array}$ & $\begin{array}{c}52.03 \\
(18.01)\end{array}$ & $\begin{array}{c}100.72 \\
(16.35)\end{array}$ & $\begin{array}{c}47.25 \\
(11.45)\end{array}$ \\
\hline M4 & $\begin{array}{c}66.86 \\
(12.92) \\
\end{array}$ & $\begin{array}{r}25.83 \\
(7.47)\end{array}$ & $\begin{array}{c}76.88 \\
(16.49) \\
\end{array}$ & $\begin{array}{c}47.63 \\
(18.85) \\
\end{array}$ & $\begin{array}{c}86.25 \\
(14.45) \\
\end{array}$ & $\begin{array}{l}38.33 \\
(9.20)\end{array}$ \\
\hline
\end{tabular}

Most of the nitrogen forms present in municipal wastewater are organic nitrogen at about $60 \%$ and ammonium at about $40 \%$ [37]. In this study, the average $\mathrm{N}_{\text {org }}$ and $\mathrm{NH}_{4}-\mathrm{N}$ concentrations in the affluent (M1) of $14 \pm 7$ and $26 \pm 6.4 \mathrm{mg} \cdot \mathrm{L}^{-1}$, respectively, were found, which corresponds to $65 \%$ and $35.5 \%$ of the total nitrogen, respectively. Nitrogen has a complex biogeochemical cycle, despite the multiple mechanisms involved, nitrogen removal is only achieved by means of denitrification, ammonia volatilization, nitrogen assimilation in vegetal tissue, sedimentation of dead plant material and ammonia adsorption to the bed $[6,38]$. Figure 4 shows the change of nitrogen concentration along the treatment system. The $\mathrm{N}_{\text {org }}$ is converted into $\mathrm{NH}_{4}-\mathrm{N}$ by ammonification (mineralization). During this process, the organic matter is biologically degraded in aerobic and anaerobic conditions with an optimum $\mathrm{pH}$ range between 6.5 and $8.5[6,38,39]$. Therefore, the Norg decrease along the entire treatment system with 
a global efficiency of $75.7 \%$ in HRT1, $60.5 \%$ in HRT2 and $80.8 \%$ in HRT3. In the second part of HSSFCW (from M3 to M4), a small increment was found that attributed to the accumulation of detritus $[6,11,39]$. The next step is the nitrification process; whereby the compounds with reduced nitrogen are sequentially oxidized to nitrate with the formation of nitrite as an intermediate compound, which means that the oxygen is the terminal electron acceptor $[6,39,40]$. The anaerobic conditions of UAF (M2) promoted the conversion of organic nitrogen to ammonia with a result of $20.7 \%$ and $79.1 \%$ final concentrations, respectively, with a significant difference $(p \leq 0.05)$, thus reducing the nitrification and the formation of nitrates. Removal of total nitrogen in UAF occurs mostly due to the reduction of nitrate under the anaerobic conditions. Besides, municipal wastewater is characterized by low concentrations of nitrates and nitrites [39]. The average nitrate concentration obtained at sampling point M1, $0.086 \pm 0.042 \mathrm{mg} \cdot \mathrm{L}^{-1}$, and the average nitrite concentration, $0.022 \pm 0.007 \mathrm{mg} \cdot \mathrm{L}^{-1}$, confirmed this. During the next sampling points, the nitrate continued to decrease; the mean value found at M2 was $0.037 \pm 0.024 \mathrm{mg} \cdot \mathrm{L}^{-1}, \mathrm{M} 30.017 \pm 0.11 \mathrm{mg} \cdot \mathrm{L}^{-1}$ and $\mathrm{M} 40.007 \pm 0.007 \mathrm{mg} \cdot \mathrm{L}^{-1}$. Finally, the nitrate could be reduced in anoxic conditions to gaseous nitrogen by means of denitrification, which is considered the main mechanism for nitrogen removal $[6,41]$. In general there are significant differences between the treatment stages for $\mathrm{N}_{\text {tot}}$, $\mathrm{N}_{\text {org }}$ and $\mathrm{NH}_{4} \mathrm{~N}$; regarding the retention time, the $\mathrm{N}_{\text {tot }}$ and $\mathrm{N}_{\text {Org }}$ showed significant differences between HRT1 and HRT3 as well as between HRT2 and HRT3.
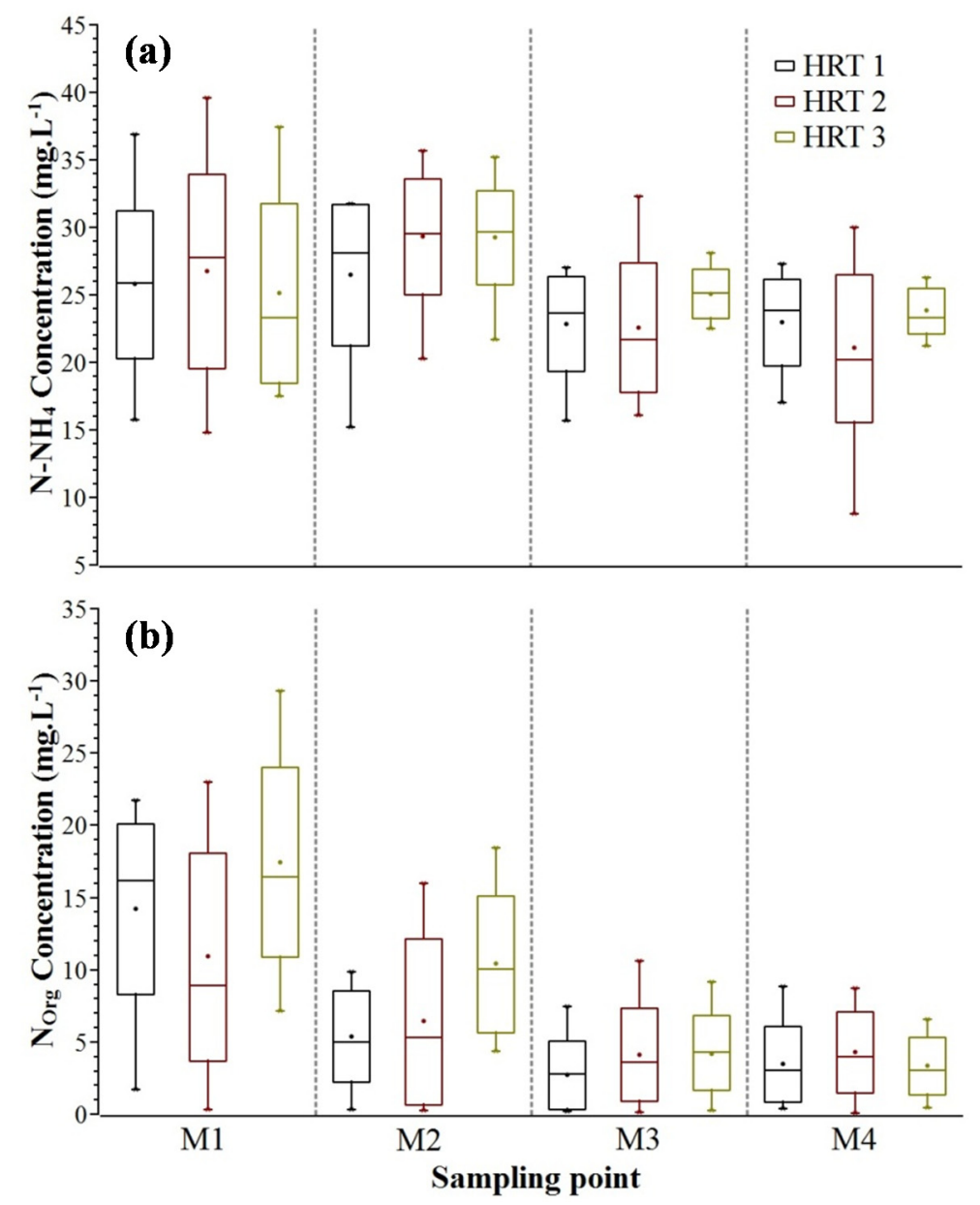

Figure 4. Plot of $\mathrm{N}-\mathrm{NH}_{4}\left(\mathrm{mg} \cdot \mathrm{L}^{-1}\right)(\mathbf{a})$ and $\mathrm{Norg}\left(\mathrm{mg} \cdot \mathrm{L}^{-1}\right)(\mathbf{b})$, with maximum and minimum values and standard deviation. 
When the objective is to remove nutrients from municipal wastewater, several authors report that 10 days of retention time is required $[25,42]$ to remove any constituent. The hydraulic retention time recommended as a prescriptive scaling factor to wetland design is between 10 and 13 days [8]. In this study, the treatment system removal of nitrogen and phosphorus showed a removal efficiency of $32.5 \%$ and $43.8 \%$, respectively, in the HRT1; $30 \%$ and $24.2 \%$ in the HRT2; and, finally, $32.9 \%$ and $30.2 \%$ in the HRT3.

Phosphorous removal is governed mainly by sorption processes on the media that is used, and phosphorus can be stored in the accumulated sediments [43]. The largest decrease of $P_{\text {tot }}$ was observed in the UAF at sample points M1 and M2 $(p \leq 0.05)$, as is shown in the Figure 5; since the retention of phosphorus in previous units is mostly due to sedimentation of particulate fraction [39]. Removal of up to $37 \%$ was measured and is attributed, primarily, to adsorption on the biofilm formed on tezontle. The biofilm begins to form by a natural process on the tezontle surface. Then, the oldest layers are detached while a newer layer is formed, and finally the biofilm settles on the bottom of the UAF. This process is repeated constantly. When the sediment reaches a determined volume, it is removed with the sludge purge where the phosphorus contained in the biofilm is removed [24].

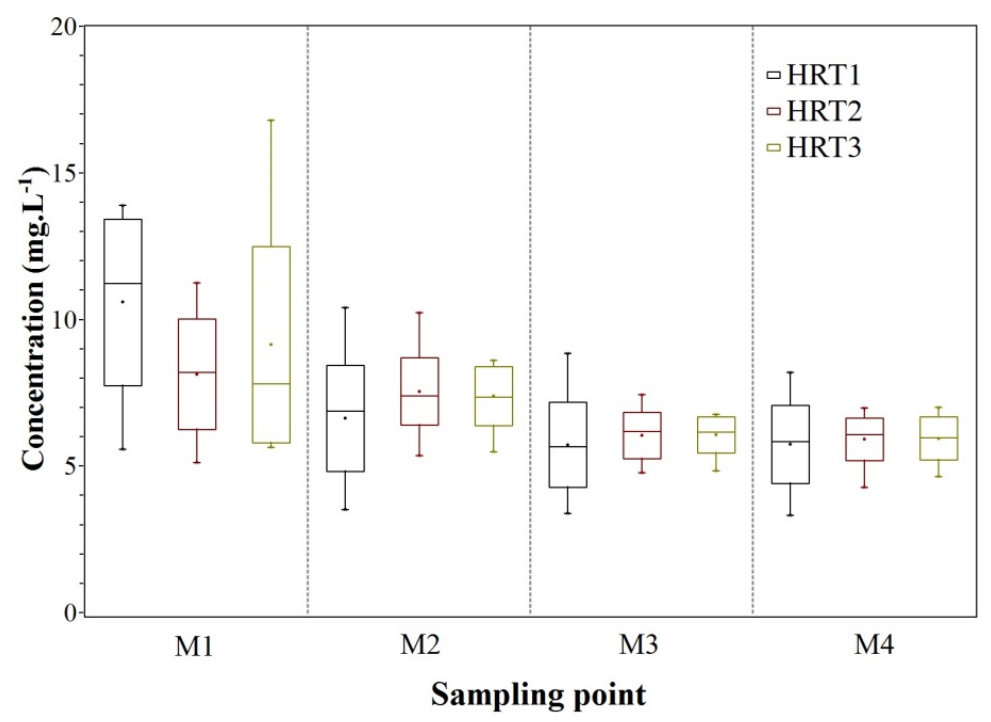

Figure 5. Plot of $\mathrm{P}_{\text {tot }}\left(\mathrm{mg} \cdot \mathrm{L}^{-1}\right)$, with maximum and minimum values and S.D.

The classic approach for treating wastewater from small communities has generally been with septic tanks [44]. Vymazal and Kröpfelová [39] report an average efficiency for previous treatment stages, such as septic and Imhoff tanks of $40.1 \%$ in BOD, $37 \%$ in COD, $25.8 \%$ in $\mathrm{N}_{\text {Org }},-1.8 \%$ in $\mathrm{NH}_{4}-\mathrm{N}_{\text {, }}$ $8.8 \%$ in $\mathrm{N}_{\text {tot }}$ and $10.5 \%$ in $\mathrm{P}_{\text {tot. }}$ Population growth and environmental conditions influence the factors used for the selection of biological wastewater treatment. The efficiency of treatment required as well as the size and cost of systems have led to implementation of new anaerobic technologies as shown in Table 3. This Table reflects the best removal efficiencies achieved by this study and compares the results with other studies where anaerobic technology treatment was used previous to a horizontal subsurface constructed wetland in order to treat municipal wastewater. 
Table 3. Pollutant removal efficiency comparison (\%).

\begin{tabular}{|c|c|c|c|c|c|c|c|c|c|c|c|c|c|c|c|c|c|}
\hline \multirow{2}{*}{ Case Study } & \multicolumn{6}{|c|}{ Anaerobic Treatment } & \multicolumn{6}{|c|}{ Constructed Wetland (CW) } & \multicolumn{5}{|c|}{ Global Efficiency } \\
\hline & 1 & 2 & 3 & 4 & 6 & 7 & 1 & 2 & 3 & 5 & 6 & 7 & 1 & 2 & 3 & 6 & 7 \\
\hline $\begin{array}{l}\text { Wastewater } \\
\text { Treatment }\end{array}$ & $\mathrm{UAF}^{\mathrm{a}}$ & UAF & $\mathrm{UASB}^{\mathrm{b}}$ & TSUAR $^{c}$ & $\mathrm{ABR}^{\mathrm{d}}$ & UASB & $\mathrm{HSSCW}^{\mathrm{e}}$ & $\mathrm{HSSCW}$ & $\mathrm{HSSCW}$ & $\mathrm{HSSCW}$ & $\mathrm{SFCW}^{\mathrm{f}}$ & $\begin{array}{c}\mathrm{SFCW} \\
\mathrm{HSSCW}\end{array}$ & $\begin{array}{c}\text { UAF } \\
\text { HSSCW }\end{array}$ & $\begin{array}{c}\mathrm{ST}^{\mathrm{g}} \\
\mathrm{UAF} \\
\mathrm{HSSCW}\end{array}$ & $\begin{array}{c}\text { UASB } \\
\text { HSSCW }\end{array}$ & $\begin{array}{c}\text { ABR } \\
\text { SFCW } \\
\text { HSSCW }\end{array}$ & $\begin{array}{c}\text { UASB } \\
\text { SFCW } \\
\text { HSSCW }\end{array}$ \\
\hline BOD & $79.8 \pm 9.0$ & $56.6 \pm 2.1$ & 63.2 & 70 & - & 44.8 & $38.4 \pm 35.8$ & $50.6 \pm 21.7$ & 78 & $79-82$ & - & 76.6 & $89.5 \pm 4.4$ & 78.1 & 92 & - & 87.1 \\
\hline COD & $76.1 \pm 7.5$ & $49.6 \pm 2.6$ & $\approx 61$ & 80 & $30.3 \pm 1.4$ & 49.4 & $44.7 \pm 29.5$ & - & 78 & $78-82$ & $78.1 \pm 2.3$ & 70.9 & $84.3 \pm 4.0$ & 81.1 & 91 & $81.2 \pm 2.3$ & 85.3 \\
\hline $\mathrm{N}_{\text {tot }}$ & $23.2 \pm 10.7$ & - & - & - & $31.3 \pm 1.3$ & - & $30.0 \pm 8.0$ & - & $\approx 24$ & - & $83.4 \pm 2.5$ & - & $33.0 \pm 17.7$ & - & $\approx 27$ & $82.3 \pm 1.9$ & - \\
\hline $\mathrm{P}_{\text {tot }}$ & $35.4 \pm 15.5$ & - & 35 & - & $34.4 \pm 2.2$ & - & $21 \pm 9.9$ & - & 38 & 15 & $61.2 \pm 2.1$ & - & $43.8 \pm 12.3$ & - & 60 & $67.2 \pm 2.3$ & - \\
\hline HRT (h) & 18 & $<8$ & 8 & 48 & 110 & $5.5-10$ & 72 & $<24$ & 120 & $8.9-9.0$ & 7 & _- & _- & _- & _- & _- & _- \\
\hline
\end{tabular}

Notes: 1 This study, 2 [44], 3 [46], 4 [49], 5 [47], 6 [45], 7 [21]; ${ }^{a}$ UAF: Up-flow anaerobic filter, ${ }^{b}$ UASB: Up-flow anaerobic sludge blanket; ${ }^{\mathrm{c}}$ TSUAR: Two-step upflow anaerobic reactor; ${ }^{\mathrm{d}}$ ABR: Anaerobic baffled reactor; ${ }^{\mathrm{e}} \mathrm{HSSCW}$ : Horizontal subsurface flow constructed wetland, ${ }^{\mathrm{f}}$ SFCW: Surface flow constructed wetland, ${ }^{\mathrm{g}}$ ST: Septic tank. 
With other anaerobic technologies, the UAF process has demonstrated a good performance for removal of organic matter and phosphorus. Nitrogen removal was slightly lower compared to the result of Ye et al. [45], where it used a full-scale anaerobic baffled reactor (ABR) followed by a constructed wetland with a total retention time of $124 \mathrm{~h}$, with a temperature between 20 and $25^{\circ} \mathrm{C}$, an $\mathrm{HSSFCW}$ area of $297 \mathrm{~m}^{2}$, under a hydraulic loading of $50 \mathrm{~m}^{3} \cdot\left(\mathrm{m}^{2} \cdot \text { day }\right)^{-1}$, and with the start-up phase of nine months; however, the HRT tested in the HSSFCW was nine times shorter. Constructed wetlands coupled with anaerobic treatments in these studies, had some differences with regard to the wetland type, the type of plants used, granular media, climate and the retention time or the system configuration. The BOD removal efficiency found in this study was similar to the efficiency reported by Villegas et al. [44], who also worked in tropical conditions, with a UAF with an HRT of $8 \mathrm{~h}$ while the HSSCW used an HRT shorter than one day, an area of approximately of $107 \mathrm{~m}^{2}$ and a mean water flow of $1.85 \pm 0.4 \mathrm{~L} \cdot \mathrm{s}^{-1}$. While the $\mathrm{N}_{\text {tot }}$ removal efficiency was slightly higher in the study of El-Khateeb and El-Gohary [46], who assessed the capability of a system consisting of an up-flow anaerobic sludge blanket (UASB) reactor followed by HSSCW. This system was implemented in an arid and semi-arid zone, the HSSCW was planted with a density of three rhizomes per $\mathrm{m}^{2}$, in an area of $2 \mathrm{~m}^{2}$, and operated an HRT of 5 days while the UASB retention time was of $8 \mathrm{~h}$, meaning a longer HRT compared to that used in the present study. The $\mathrm{P}_{\text {tot }}$ removal efficiency was higher than that found by El Hamuri et al. [47] where limestone aggregates were used as filling material. In this study the behavior of a HSSCW used as post-treatment behind a two-step upflow anaerobic reactor (TSUAR) in Mediterranean conditions is evaluated. The HSSCW had an area of $28 \mathrm{~m}^{2}$, a water flow of $9.5 \mathrm{~m}^{3} \cdot \mathrm{day}^{-1}$ and HRT of $9 \mathrm{~h}$. The global efficiencies reached for organic matter removal (up to $80 \%$ ) were as expected, and they were comparable with to treatment systems with combined high rate anaerobic reactors and constructed wetlands as surface flow constructed wetlands (SFCW) with HSSCW. Better nitrogen removal has been found when constructed wetlands are combined with anaerobic treatment than for HSSCW units without a treatment stage previous. In addition, the area decrease is noticeable when the $\mathrm{P}-\mathrm{k}-\mathrm{C}^{*}$ kinetic removal model [8] is applied to the design data, considering an influent BOD concentration (M1) of $259 \pm 58 \mathrm{mg} \cdot \mathrm{L}^{-1}$ and a target concentration of $60 \mathrm{mg} \cdot \mathrm{L}^{-1}$ according to Mexican regulations [48], making it possible to calculate a wetland area decrease of $27 \%$.

\section{Conclusions}

Mean global efficiencies found for the complete system for the lower HRT (two days) were: $89.5 \% \pm 4.4 \%$ for $\mathrm{BOD}, 84.2 \% \pm 4.0 \%$ for $\mathrm{COD}, 32.5 \% \pm 13.2 \%$ for total nitrogen $\left(\mathrm{N}_{\mathrm{tot}}\right)$ and $43.8 \% \pm 12.3 \%$ for total phosphorous ( $\mathrm{P}_{\text {tot }}$ ). Mean removal efficiencies for the higher HRT (four days), were $86.1 \% \pm 3.1 \%$ for BOD, $81.7 \% \pm 3.9 \%$ for COD, $32.9 \% \pm 17.7 \%$ for $\mathrm{N}_{\text {tot }}$ and $30.2 \% \pm 16.0 \%$ for

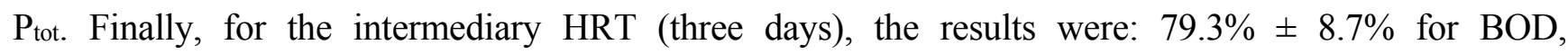
$85.6 \% \pm 3.1 \%$ for COD, $30.0 \% \pm 16.8 \%$ for $\mathrm{N}_{\text {tot }}$ and $24.2 \% \pm 17.7 \%$ for $\mathrm{P}_{\text {tot. }}$ The best mean efficiencies reached in the UAF stage for COD, BOD, $\mathrm{N}_{\text {tot }}$ and $\mathrm{P}_{\text {tot }}$ were $79.8 \%, 76.1 \%, 23.2 \%$ and $35.4 \%$, respectively, at the HRT1. The best removal for nitrogen in the HSSCW was reached with a detention time of three and four days, with the longer time allowing further progress in the nitrogen cycle. The HRT recommended for phosphorus removal for UAF is two days, while for HSSCW an HRT of at least three days is recommended. In other words, two days is adequate to remove organic matter, but when the objective is to remove organic matter and nutrients a three-day HRT is recommended. Moreover, it would be 
interesting to test HRTs longer than four days for HSSCW and to conduct a more comprehensive investigation of the interactions on the support media.

The UAF was responsible for the organic matter reduction while nitrogen removal was performed by the HSSCW. The goal of reducing the land surface required by the wetland was achieved, since the organic matter removal by the UAF decreased the land requirements moderately, and could lessen early clogging in the constructed wetland.

\section{Acknowledgments}

The authors would like to thank to State Water Commission (Comisión Estatal del Agua, CEA-Jalisco) for its support during the experimental stage and to National Council of Science and Technology (Consejo Nacional de Ciencia y Tecnología, CONACYT) for the scholarship granted to student María de la Luz Merino Solís and the support of the Project 128209 (FOMIX CONACY-Veracruz). Also, a special thanks to MSc Leonel Hernández Mena for his constructive comments and to Dana Erickson and Walter Meyer for their linguistic contribution.

\section{Author Contributions}

López-López Alberto and de Anda José conceived and designed the project and also they contributed reagents, materials and analysis tools; Merino-Solís María L. and Villegas Edgardo performed the experiments during the monitoring stage and performed the data analysis. All the authors wrote the paper.

\section{Conflicts of Interest}

The authors declare no conflict of interest.

\section{References}

1. Cui, L.; Zhu, X.; Ma, M.; Ouyang, Y.; Dong, M.; Zhu, W.; Luo, S. Phosphorus sorption capacities and physicochemical properties of nine substrate materials for constructed wetland. Arch. Environ. Contam. Toxicol. 2008, 55, 210-217.

2. Smith, V.H. Eutrophication. In Encyclopedia of Inland Waters; Likens, G.E., Ed.; Elsevier: Oxford, UK, 2009; Volume 3, pp. 61-73.

3. Yates, C.R.; Prasher, S.O. Phosphorus reduction from agricultural runoff in a pilot-scale surface-flow constructed wetland. Ecol. Eng. 2009, 35, 1693-1701.

4. Akratos, C.S.; Tsihrintzis, V.A. Effect of temperature, HRT, vegetation and porous media on removal efficiency of pilot-scale horizontal subsurface flow constructed wetland. Ecol. Eng. 2007, 29, 173-191.

5. Puigagut, J.; Villaseñor, J.; Salas, J.J.; Bécares, E.; García, J. Subsurface-flow constructed wetlands in Spain for the sanitation of small communities: A comparative study. Ecol. Eng. 2007, 30, 312-319.

6. Vymazal, J. Review: Removal of nutrients in various types of constructed wetlands. Sci. Total Environ. 2007, 380, 48-65.

7. Langergraber, G. Modeling of processes in subsurface flow constructed wetlands: A review. Vadose Zone J. 2008, 7, 830-842. 
8. Kadlec, R.; Wallace, S. Treatment Wetlands, 2nd ed.; CRC Press, Taylor \& Francis Group: Boca Raton, FL, USA, 2009; pp. 3-10, 715-734.

9. Matamoros, V.; Bayona, J.M. Behavior of emerging pollutants in constructed wetlands. Handb. Environ. Chem. 2008, 5, 199-217.

10. Reed, C.; Crites, R.W.; Middlebrooks, E.J. Natural Systems for Waste Management and Treatment; Mc Graw Hill Co.: New York, NY, USA, 1995; pp. 173-178.

11. U.S. EPA. Manual Constructed Wetlands Treatment of Municipal Wastewater; Office of Research and Development: Cincinnati, OH, USA, 2000.

12. Wang, X.; Bai, X.; Qiu, J.; Wang, B. Municipal wastewater treatment with pond-CW system: A case study. Water Sci. Technol. 2005, 51, 325-329.

13. Sim, C.; Yusoff, M.; Shutes, B.; Ho, S.; Mansor, M. Nutrient removal in a pilot and full scale constructed wetland, Putrajaya city, Malaysia. J. Environ. Manag. 2008, 88, 307-317.

14. Ye, F.; Li, Y. Enhancement of nitrogen removal in towery hybrid constructed wetland to treat domestic wastewater for small rural communities. Ecol. Eng. 2009, 35, 1043-1050.

15. De la Varga, D.; Díaz, M.A.; Ruiz, I.; Soto, M. Avoiding clogging in constructed wetlands by using anaerobic digesters as pre-treatment. Ecol. Eng. 2013, 52, 262-269.

16. Knowles, P.R.; Griffin, P.; Davies, P.A. Complementary methods to investigate the development of clogging within a horizontal sub-surface flow tertiary treatment wetland. Water Res. 2010, 44, 320-330.

17. Saeed, T.; Sun, G. A review on nitrogen and organics removal mechanisms in subsurface flow constructed wetlands: Dependency on environmental parameters, operating conditions and supporting media. J. Environ. Manag. 2012, 112, 429-448.

18. Barros, P.; Ruiz, I.; Soto, M. Performance of an anaerobic digester-constructed wetland system for a small community. Ecol. Eng. 2008, 33, 142-149.

19. Ansola, G.; González, J.M.; Cortijo, R.; de Luis, E. Experimental and full-scale pilot plant constructed wetlands for municipal wastewater treatment. Ecol. Eng. 2003, 21, 43-52.

20. Álvarez, J.A.; Ruíz, I.; Soto, M. Anaerobic digesters as a pretreatment for constructed wetlands. Ecol. Eng. 2008, 33, 54-67.

21. Ruiz, I.; Díaz, M.A.; Crujeiras, B.; García, J.; Soto, M. Solids hydrolysis and accumulation in a hybrid anaerobic digester-constructed wetlands system. Ecol. Eng. 2010, 36, 1007-1016.

22. Morel, A.; Diener, S. Greywater Management in Low and Middle-Income Countries, Review of Different Treatment Systems for Households or Neighbourhoods; Swiss Federal Institute of Aquatic Science and Technology (Eawag): Dubendorf, Switzerland, 2006; pp. 27-30.

23. Manariotis, I.; Grigoropoulos, S. Restart of anaerobic filters treating low-strength wastewater. Bioresour. Technol. 2008, 99, 3579-3589.

24. López-López, A.; Albarrán-Rivas, M.G.; Hernández-Mena, L.; León-Becerril, E. An assessment of an anaerobic filter packed with a low-cost material for treating domestic wastewater. Environ. Technol. 2013, 34, 1151-1159.

25. Trang, N.; Konnerup, D.; Schierup, H.; Chiem, N.; Tuan, L.; Brix, H. Kinetics of pollutant removal from domestic wastewater in a tropical horizontal subsurface flow constructed wetland system: Effects of hydraulic loading rate. Ecol. Eng. 2010, 36, 527-535. 
26. Ramsar Information Sheet, Version 2006-2008. Available online: http://ramsar.conanp.gob.mx/ docs/sitios/FIR_RAMSAR/Jalisco/Lago\%20de\%20Chapala/LAGO_DE_CHAPALA.pdf (accessed on 13 March 2015).

27. Rubel, F.; Kottek, M. Observed and projected climate shifts 1901-2100 depicted by world maps of the Köppen-Geiger climate classification. Meteorol. Z. 2010, 19, 135-141.

28. López-López, A.; Vallejo-Ramírez, R.; Méndez-Romero, D.C. Evaluation of a combined anaerobic and aerobic system for the treatment of slaughterhouse wastewater. Environ. Technol. 2010, 31, 319-326.

29. Zurita, F.; de Anda, J.; Belmont, M.A. Treatment of domestic wastewater and production of commercial flowers in vertical and horizontal subsurface-flow constructed wetland. Ecol. Eng. 2009, 35, 861-869.

30. Trejo-Téllez, L.I.; Ramírez-Martínez, M.; Gómez-Merino, F.C.; García-Albarado, J.C. Physical and chemical evaluation of volcanic rocks and its use for tulip production. Rev. Mex. Cienc. Agríc. 2013, 5, 863-876.

31. Konnerup, D.; Koottatep, T.; Brix, H. Treatment of domestic wastewater in tropical, subsurface flow constructed wetlands planted with Canna and Heliconia, Ecol. Eng. 2009, 35, 248-257.

32. Lin, Y.F.; Jing, S.R.; Lee, D.Y.; Wang, T.W. Nutrient removal from aquaculture wastewater using a constructed wetlands system. Aquaculture 2002, 209, 169-184.

33. Kincanon, R.; McAnally, S. Enhancing commonly used model predictions for constructed wetland performance: As-built design considerations. Ecol. Model. 2004, 174, 309-322.

34. Zurita, F.; de Anda, J.; Belmont, M.A. Performance of laboratory-scale wetlands planted with tropical ornamental plants to treat domestic wastewater. Water Qual. Res. J. Can. 2006, 41, 410-417.

35. American Public Health Association (APHA). Standard Methods for the Examination of Water and Wastewater, 20th ed.; American Public Health Association, American Water Works Association, Water Environment Federation: Washington, DC, USA, 1999.

36. Statgraphics Centurion, version XVI; StatPoint Tecnologies, Inc.: Warrenton, VA, USA, 2011.

37. Sedlak, R.I. Phosphorus and Nitrogen Removal from Municipal Wastewater: Principles and Practice, 2nd ed.; CRC Press, Lewis publishers: Boca Raton, FL, USA, 1991; p. 3.

38. Wallace, S.D.; Knight, R.L. Small-Scale Constructed Wetland Treatment Systems: Feasibility, Design Criteria and O\&M Requirements; Water Environment Research Foundation (WERF): Alexandria, VA, USA, 2006; pp. 4-21.

39. Vymazal, J.; Kröpfelova, L. Wastewater Treatment in Constructed Wetlands with Horizontal Sub-Surface Flow; Alloway B.J., Trevors J.T., Eds.; Springer: Berlin, Germany, 2008; Volume 14, pp. 40, 277-278.

40. Vymazal, J. Review: Horizontal sub-surface flow and hybrid constructed wetlands systems for wastewater treatment. Ecol. Eng. 2005, 25, 478-490.

41. Maltais, G.; Maranger, R.; Brisson, J.; Chazarenc, F. Nitrogen transformations and retention in planted and artificially aerated constructed wetlands. Water Res. 2009, 43, 535-545.

42. Yousefi, Z.; Mohseni-Bandpei, A. Nitrogen and phosphorus removal from wastewater by subsurface wetlands planted with Iris pseudacorus. Ecol. Eng. 2010, 36, 777-782.

43. Green, M.; Safray, I.; Agami, M. Constructed wetlands for river reclamation: experimental design, start-up and preliminary results. Bioresour. Technol. 1995, 55, 157-162. 
44. Villegas, J.D.; Guerrero, J.; Castaño, J.M.; Paredes, D. Septic tank (ST)-Up flow anaerobic filter (UFAF)-subsurface flow constructed wetland (SSF-CW) systems aimed at wastewater treatment in small localities in Colombia. Rev. Tec. Fac. Ing. Univ. Zulia 2006, 29, 269-281.

45. Ye, C.; Li, L.; Zhang, J.; Yang, Y. Study on ABR stage-constructed wetland integrated system in treatment of rural sewage. In Proceedings of the 2011 International Conference on Environmental Science and Engineering, Bali Island, Indonesia, 1-3 April 2011.

46. El-Khateeb, M.A.; El-Gohary, F.A. Combining UASB technology and constructed wetland for domestic wastewater reclamation and reuse. Water Sci. Technol. Water Supply 2003, 3, 201-208.

47. El Hamouri, B.; Nazih, J.; Lahjouj, J. Subsurface-horizontal flow constructed wetland for sewage treatment under Moroccan climate conditions. Desalination 2007, 215, 153-158.

48. Secretaría de economía, Norma Oficial Mexicana NOM-001-ECOL-1996. Available online: http://www.economia-noms.gob.mx/normas/noms/1997/001-ecol.pdf (accessed on 12 December 2014).

49. El Hafiane, F.; El Hamouri, B. Anaerobic reactor/high rate pond combined technology for sewage treatment in the Mediterranean area. Water Sci. Technol. 2005, 52, 125-132.

(C) 2015 by the authors; licensee MDPI, Basel, Switzerland. This article is an open access article distributed under the terms and conditions of the Creative Commons Attribution license (http://creativecommons.org/licenses/by/4.0/). 